\title{
ROLE OF EMOTIONAL INTELLIGENCE IN CAREER ADVANCEMENT OF UNIVERSITY TEACHERS
}

\section{Farah Fida $^{1^{*}}$, Nasreen Akhter ${ }^{2}$, Sabiha Iqbal ${ }^{3}$, Aks E Noor ${ }^{4}$, Lubna Salamat ${ }^{5}$}

${ }^{1 *}$ Ph.D. Scholar, Department of Education, The Islamia University of Bahawalpur, Pakistan; ${ }^{2}$ Professor of Education, Chairperson Special Education, The Islamia University of Bahawalpur, Pakistan; ${ }^{3}$ Assistant Professor, Department of Education, Islamia University Bahawalpure, Pakistan; ${ }^{4} \mathrm{Ph}$.D. scholar, Special Education, Asia E University, Malyasia; ${ }^{5} \mathrm{Ph} . \mathrm{D}$. Scholar, Department of Education, The Islamia University of Bahawalpur, Pakistan.

Email: ${ }^{1 *}$ farahahsan61@gmail.com, ${ }^{2}$ nasreen.akhtar@iub.edu.pk, ${ }^{3}$ sabiha.iqbal@iub.edu.pk, ${ }^{4}$ aksenoor@ gmail.com, ${ }^{5}$ lubnasalamat786@gmail.com

\section{Article History: Received on $18^{\text {th }}$ March 2021, Revised on $27^{\text {th }}$ April 2021, Published on $29^{\text {th }}$ April 2021}

\begin{abstract}
Purpose of the study: This paper aimed to discuss the theories of emotional intelligence and its role in career advancement in the institutions of working in the field of higher education.

Methodology: A critical review of the literature is conducted to determine the most common theories of emotional intelligence, the concept of career advancement, and how emotional intelligence contribute to an individual's career advancement. This article also tries to organize various components involved in the career advancement of the teachers working in the universities. The data were collected from various national and international journal articles, books, and other relevant material.
\end{abstract}

Main Findings: Analysis of literature revealed that there was a positive and significant impact of emotional intelligence on the career advancement of university teachers. It also explored the positive and negative elements that affect an employee's career advancement.

Application of this study: The outcomes of the study would be helpful for university teachers to understand their level of emotional intelligence, which contribute to increasing their performance in term of career advancement.

Novelty/Originality of this study: In the context of Pakistan, there were no such studies available in the literature that investigated on importance of emotional intelligence on the career advancement of university teachers.

Keywords: Emotional Intelligence, University Teachers, Career Advancement, Career Success, Higher Education.

\section{INTRODUCTION}

\section{Concept of emotional intelligence}

The terms "emotional" and "intelligent" have various connotations. Such an emotion is a psychological state associated with a person's feelings, ideas, behavioral attitude, and amount of happiness or melancholy. In contrast, intelligence is related to an individual's quality of self-awareness, social awareness, comprehension, reasoning, planning, creativity, critical thinking, and problem-solving (Goleman, 2001). Therefore, emotional intelligence is tied to an individual's cognitive ability in noticing, using, comprehending, managing, and dealing with one's own emotions (Goh et al., 2003). For researchers, the idea of emotional intelligence and its interpretations have remained most popular in the standard and theoretical literature. Various researchers contributed to it and described emotional intelligence to their best abilities. According to renowned researcher and recognized as the father of emotional intelligence Goleman (2001), emotional intelligence (E.I.) is related to a person's abilities for understanding and regulating his or her emotions in and others on a broad level. Literature exposed that three primary theorists worked on emotional intelligence: Bar-On, Mayer and Salovey, and Daniel Goleman. Three key theorists dominate research in the subject of emotional intelligence: Bar-On, Mayer and Salovey, and Daniel Goleman. Bar-On coined the phrase "emotion quotient," which defines emotional intelligence as the ability to comprehend oneself and others, relate to others, and adapt to and cope with one's immediate circumstances to be more successful in dealing with environmental demands (Bar-On, 1997). Mayer and Salovey (1997) opposed the definitions of previous researchers and demarcated emotional intelligence and stated that emotional intelligence deals with the abilities of a person regarding how to perceive, evaluate, and express emotion correctly; the abilities of a person regarding assessing and producing feelings when they facilitate thought; the abilities of a person regarding understanding emotion and emotional knowledge; and the abilities of a person regarding how to regulate emotions to promote emotional and intellectual development. According to Duque, Garcia, and Hurtado (2019), it is a mental ability, implying that emotionally intelligent people interpret emotions more accurately. This enables people to properly utilize emotions to enhance thinking, understand them and their significance, and control their own and others' emotions more effectively. In a word, emotional intelligence (E.I.) is the meta-ability to notice and understand emotions and manage them effectively and adaptively.

\section{Elements of emotional intelligence}

Daniel Goleman, an American psychologist who interpreted emotional intelligence, proposed five aspects that describe emotional intelligence. According to Goleman (1995), emotional intelligence has five key components: self-awareness, 
self-regulation, motivation, empathy, and social skills.

\section{Career development and career advancement}

In literature, career advancement is defined as employees' rights to receive promotions, their ability to rise in administrative roles and earn a higher salary (Miner, Chen \& Yu, 1991).

\section{Role of emotional intelligence in career success, career development}

Emotional intelligence plays a vital role in career advancements. Many pieces of evidence in the literature, such as Gabel et al. (2017), investigated the function of emotional intelligence in professional adjustment and success, finding that emotional intelligence played a favorable role in career adjustment and success. Sultana, Yousaf, Khan, and Saeed (2016) researched to discover the impact of emotional intelligence on perceived career success. Their research revealed a significant relationship between emotional intelligence and perceived career success.

\section{Justification of the study}

This present research study aimed to investigate the notion of emotional intelligence, emotional intelligence models, the concept of career progression, and the role of emotional intelligence in professional success and career development. This study highlights the various popular theories and models available and accessible in the literature on emotional intelligence.

\section{Statement of the problem}

In the context of Pakistani university teachers, it has been noticed that there had a lack of awareness regarding the right notion of emotional intelligence, the most renowned models representing emotional intelligence, the concept of career progression, and the role of emotional intelligence in career success and career development. As a result, this study emphasizes these components involved in career progression by disclosing from the body of literature through the objectives listed below.

\section{Objectives of the study}

- To study the concept of emotional intelligence

- To review the models of emotional intelligence

- To review the concept of professional development and career success

- Explore the role of emotional intelligence in career success and professional advancement of university teachers.

\section{Research Questions}

- What is emotional intelligence?

- What are models of emotional intelligence?

- What are professional development and career success

- What is the role of emotional intelligence in career advancement and career success

\section{Conceptual framework of the study}

The investigator's thought or idea that displays an appropriate direction in which the investigation will be conducted is known as the conceptual framework. As a result, the conceptual framework of this study was based on Goleman's idea of emotional intelligence, which comprises five components. These components are recognized as self-awareness, emotion management, self-motivation, empathy, and social skills (Goleman, 2001). Similarly, according to Herzberg et al., $\underline{(1959)}$ ) 's two-factor theory, some factors that lead to employee job satisfaction are known as motivators, such as (achievement, recognition, career advancement, level of responsibility, and so on), while some factors that lead to employee job dissatisfaction are known as dis-satisfier factors, such as organizational policies, salary, supervision, job security, working conditions, and so on.

Figure 1 shows the conceptual framework of Emotional Intelligence utilized in this paper, comprising the effect of "selfawareness, managing emotions, motivating oneself, empathy, and social skills on career advancement.

\section{RESEARCH METHODOLOGY}

In this paper, the researcher evaluated past researches regarding the role of emotional intelligence in career advancement, career growth, and career accomplishment of the employees working in various sectors. The procedure of library search was adopted. Libraries in reach of researchers, including access to internet data available on unpaid sites, were accessed. After reading and evaluations fifty-six of the pieces of literature (articles and books) on the topic, descriptions regarding subsections were elaborated citing sources. 


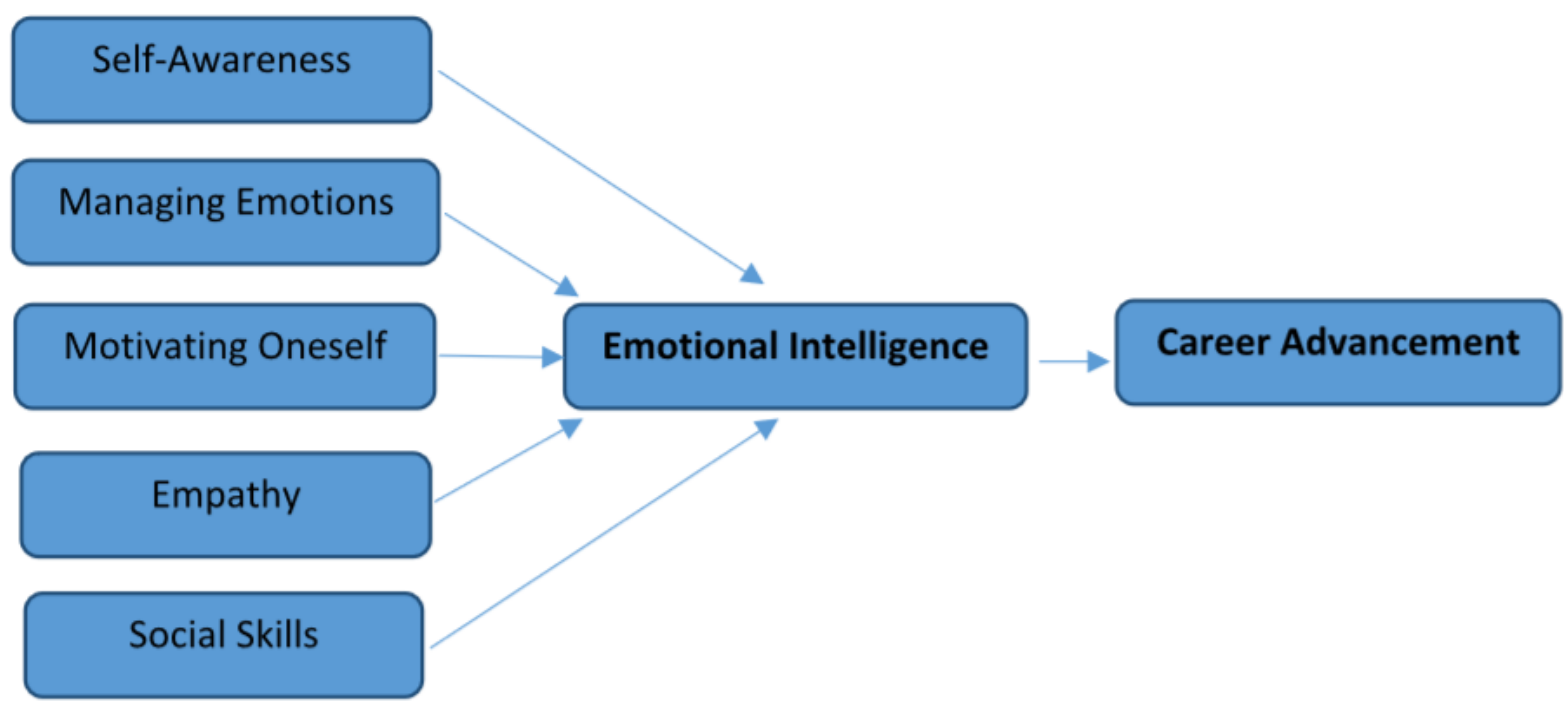

Figure 1: The conceptual framework for Emotional Intelligence and career advancement (adapted from Goleman, 1995)

\section{Theoretical Review/ Analysis}

Emotional intelligence is defined in the literature as individual abilities for recognizing, utilizing, and controlling their own emotions in productive ways for lowering stress, communicating effectively, empathizing with others, overcoming challenges, and diffusing disputes. Emotional intelligence guides a person to show his reaction in different situations in the outer form to show his inner feelings.

Many researchers worked on human behavioral issues and pointed out concepts for scholars of psychology and readers of psychological wellbeing of human developed materials. Literature indicates that the first investigators to investigate and define emotional intelligence were Salovey and Mayer (1990). They demarcated emotional intelligence as "the ability to monitor one's own and others' moods and emotions, to distinguish between them, and to utilize this information to guide one's thinking and actions." Education guides a person to behave in different situations, keeping the scenarios and environment according to people. Formal and informal education guides individuals to alter their behavior in different situations to behave like civilized persons and show authority to deal with a situation tactfully. According to different academics, everyone has the power to alter their emotions to improve their thinking, judgment, and behavior.

Thorndike (1920) enlarged and integrated three crucial components into his definition of emotional intelligence, including abstract intelligence, mechanical intelligence, and social intelligence. This indicated that every human behavior depicts his power to tackle a situation using his power to understand a phenomenon. The intelligence level (I.Q.) of a person undoubtedly affects the control of emotions. On the other hand, a person having a better understanding and command of social values, social structure, and social environment more boost up emotional intelligence of the persons enabling him to act according to norms of eras.

In the 1980s, other academics, including Gardner, contributed to the notion of emotional intelligence by coining the terms intra-emotional intelligence and inter-emotional intelligence. Steiner was the one who came up with the idea of E.I. (1984). The investigators Salovey and Mayer (1990) developed the concept of "emotional intelligence" due to these experts' contributions. In the years that followed, emotional intelligence was extensively investigated in the literature of organizational behavior, human resources, and management, among other areas. Furthermore, Salovey and Mayer (1990) made a significant contribution by proposing an emotional intelligence model as a subset of social intelligence that focuses on people's skills to control their own and others' emotions and moods. It aids them in distinguishing and controlling their reasoning and actions.

Emotional intelligence is defined by Mayer, Caruso, and Salovey (1999) as a person's skill towards recognizing, accessing, and producing emotions to make better judgments. Emotional intelligence also aids in the understanding and management of feelings, emotions, and emotional knowledge. According to Colman (2008), it is defined as an individual's ability to perceive, use, comprehend, manage, and handle emotions. Individuals with high emotional intelligence can recognize their own and others' emotions, use dynamic information to guide their thoughts and actions, differentiate between different feelings, identify them appropriately, and change their emotions to fit their environment.

\section{Models of Emotional Intelligence}

The majority of researchers believe that the type of measuring utilized determines the success of the hypothesis of emotional intelligence. There are three basic models of emotional intelligence that have recently been developed, including: 
1. The ability model was presented by Mayer and Salovey (1990).

2. The mixed models are presented by Bar-On (2006) and Boyatzis and Sala (2004).

3. The trait model of emotional intelligence was presented by Petrides and Furnham (2003).

Mayer and Salovey (1990) employ a different set of cognitive talents that are inter-correlated in their ability model. Emotional intelligence is considered as a standard intelligence that exploits a separate group of cognitive skills that are (1) interrelated, (2) related to other intelligence, and (3) develop with age and experience, according to $\underline{\text { Mayer and }}$ Salovey (1990), ability models. On the other hand, mixture and trait models define and quantify emotional intelligence as a set of perceived skills, abilities, and personality qualities (Mayer, Caruso, \& Salovey, 1999; Mayer, Salovey, Caruso, \& Sitarenios, 2003). An explanation of emotional intelligence models is given below.

The first component of Salovey and Mayer's (1990) ability model is perceptions of emotions, which deals with an individual's ability to identify their own and others' emotions by studying facial expressions, tone of voice, and body language (Brackett et al., 2013). The second component of the ability model is the proper use of emotions to facilitate thinking. This component discusses how to properly use emotions to boost intellectual activities and adapt to various situations. The third component is related to the understanding of one's emotions. The ability to discriminate various emotional states, as well as the causes and results of each, is the focus of the third component. Differentiating between negative emotions is an important skill in emotional knowledge, and it can help you control your emotions more effectively (Feldman Barret, Gross, Christensen, \& Benvenuto, 2001). The abilities to remain open to a wide range of emotions, recognize the relevance of feeling particular emotions in specific settings, and grasp which short- and longterm methods for emotion regulation are most effective is the final fourth component of the ability model (Gross, 1998). Shortly, the Ability model of emotional intelligence has four components including; perceptions of emotions, proper uses of emotions, understanding of one's emotions, and recognition of the relevance of feeling to particular emotions in a specific setting. The utmost motto of this model is to enable the person to be able to control the emotions in recognition of emotion regulations.

Mixed models of emotional intelligence proposed a broad description of emotional intelligence that includes mental ability as well as personality attributes such as optimism, motivation, and stress tolerance (Cherniss, 2010; U1lah \& Hamdard, 2019). The Boyatzis-Goleman and Bar-On models of emotional-social intelligence are the most prominent and extensively used mixed models (Boyatzis \& Sala, 2004). Self-awareness, self-management, social awareness, and relationship management are four components of the Boyatzis-Goleman model.

On the other hand, the Bar-On model consists of five elements: intrapersonal skills, interpersonal skills, adaptation, stress management, and moods. Petrides and Furnham (2003), the authors of the trait model, describe that it is concerned with a constellation of self-perceived, emotion-related personality qualities.

\section{Emotional Intelligence and Teachers}

After the rapid advancement in technologies and the educational sector, teaching has become more complex than traditional teaching. The parents and society of the technological era demand good behaviors of their children, better academic performance, and innovative skills in their children. But the teachers are failed to cope with the demands of the parents, society, and students. Due to this failure, heavy pressure from parents and social identities is increasing day by day, resulting in teachers' emotional disturbances. This emotional disturbance can be decreased only if teachers struggle to develop their professional and emotional intelligence for tackling said problems. Emotional intelligence empowers the teachers to control and regulate their emotions and fulfill society's demands (Ignat \& Clipa, 2012).

Every education system of the globe is useless without teachers. Teachers play a significant role in the whole process of education and deliver innovative knowledge to the students to succeed in all fields of life. It is the basic responsibility of the teachers to provide the required knowledge to the students, create their innovative skills, and behaviors for living in a society. These skills can be achieved through proper communication between teachers and students. Communication among teachers and students can lead to the quality of education (Karsli, 2008). No doubt, teachers' emotional intelligence plays a role in the working of teachers and affects their teaching quality and career performance.

\section{The concept of Career Advancement}

In the literature, workers' understanding of career advancement is described as achievement, personal recognition, balance, promotions, rewards, personal successes, position, material success, contribution, and impact. Dries (2011) says that career advancement is about how you utilize your profession to make a difference in the institution and how you use your position in the workplace to help and support the country's social and economic development through original ideas, discoveries, etc. and innovation.

Career is a notion that deals with how people develop their professional identities through professional mobility and the structure of organizations that are relevant to careers (Lahti, 2013). However, career advancement is defined as employees' rights to receive promotions, their ability to rise in administrative roles, and earn a higher salary (Miner, Chen \& Yu, 1991; Khan, Ullah 2021). Advancement in one's career motivates people to work hard to become more 
successful and productive at work. It also motivates people to perform better and offer higher-quality work, and increases workers' abilities and comprehension on the job. Furthermore, the more opportunities employees have to advance through awareness regarding qualities in one's work performance, the more likely they are to work hard and offer their best. Suppose the possibility to advance the worker is granted. In that case, it also benefits the company with which they work by retaining brilliant employees and changing retired employees to ensure that the upper jobs are constantly available.

According to Adenji et al. (2019), the extent of career advancement is a major barrier to achieving high efficiency and organizational success. However, most firms cannot provide their employees with opportunities for upward career advancement. Maimunah and Atikah (2016) say that workers are encouraged to obtain the skills and knowledge required for advancement in terms of career growth. Furthermore, career growth enables people to improve their skills, knowledge, behaviors, and capabilities while also providing motivating opportunities at work (Adenji et al., 2019; Armstrong, 2011; Tareef, 2012). Herzberg et al. (1959) identified five determinants of professional success: achievement, responsibility, work itself, acknowledgment, and progress, all of which are good predictors of job satisfaction. Supervisory, corporate rules, administration policies, salary, job circumstances, and interpersonal ties are other determinants.

\section{Career advancement $\&$ career management process}

Gerco and Kraimer (2019) emphasized the career management process. According to them, career goals are a crucial aspect of career development since they outline the intended professional outcomes such as wage raises, promotions, and skill acquisition that individuals wish to achieve (Greenhaus, 1987; Seibert et al., 2013). Individuals give their efforts, such as concentration, time, and drive, to achieve the above career results (King, 2004). In this approach, career goal formulation facilitates progress toward achieving desired outcomes. Deci and Ryan (1985) distinguished two types of career objectives. The first is extrinsic, which focuses on outward-oriented goals such as prestige, influence, and achievement as indicators of self-worth. The second type is intrinsic, which focuses on inward-oriented goals such as personal motivators such as skill and knowledge acquisition and growth, interest in job performance, and making a difference in society (William et al., $2000 \&$ Seibert et al., 2013).

Charter and Silva (2011) identified four distinct career advancement strategies among employees, such as Climbers: Employees who pursue progression in their institutions through requesting various assignments, working long hours, networking and searching for greater visibility, Hedgers: Employees who take advantage of all available career tactics to move forward in and out of their institutions, Scanners: Employees who thoroughly screen the job market and are ready to change job, if not institutions, as occasions appear, and Coasters: Employees who don't struggle much for career advancement.

Ohunakin et al., (2018) pronounced the employees' commitment to the organizations as that when workers can identify their own professional goals can move into real possible future opportunities. In this way, employees can flourish inside the organizations and when employees' skills, motives, attributes, and competencies are aligned with their career choice then their satisfaction towards their career became high. But on the other hand, investigations discovered that more than two out of three workers are disappointed with upcoming professional chances offered by their organizations (Bombuwela and Alwis, 2013; Adeniji et al., 2014; Salau et al., 2014).

Researchers of career explained that career advancement enables workers to assess their skills so that they became able to move to other professions that are more consistent with their personal goals. Moreover, workers can discover where they are fit and which duty is suitable for them in the organization (Weinert, 2001). The study of Murniati (2012) regarding employees' career advancement in senior academic administrators in Indonesia found that despite increasing academic achievement, females remain underrepresented in top leadership positions. Most of the available pieces of literature about career advancement recommend that workers' profession advancement is influenced by external factors such as societal and organizational and internal factors such as personal or individual.

Teachers can advance in their career to get high job roles such as administrator, principal, vice-principal, coordinators, headteachers, and moving from primary school to elementary, secondary, higher secondary, college, and university. Furthermore, a teacher needs advanced education, certification, training to achieve these career advancements. Moreover, the academic career system retains outstanding staff members and motivate them to increase their performance in teaching, supervision, research, profession, and other responsibilities through openings for career advancement and greater salary (Frolich et al., 2018).

\section{Emotional intelligence and career advancement}

Career advancement depends on the teacher's ability to connect with the student emotionally and a deep understanding of self-awareness, self-regulation, social awareness, and relationship management. Teaching involves intensive emotional labor and laborious hard work, leading to a very demanding and dedicated profession. The trouble for the teacher intensifies to overcome the misbehaving pupils, and thus, professional abilities and burdens come into place. Resultantly, teachers tend to feel frustration and a state of dissatisfaction with his/her profession and organization. The tackling of an odd situation depends upon the emotional intelligence of the teacher. Emotionally intelligent teachers can handle any 
situation occurred during the teaching and learning process. Teachers are expected that using emotion in the new scenario will come up and overcome odd feelings. The utmost requirement of university teachers is to assess emotional intelligence due to sudden changes in academic scenarios (Serbanescu, 2011). In his popular science book, Goleman (1994) stated that emotional intelligence is associated with greater job success than the intelligence quotient. Similarly, numerous studies have found that workers with a high level of emotional intelligence perform better than those with a low level of emotional intelligence. These measurements were taken in a prior study using a self-reporting system that included several indications of job performance such as earnings, promotions, and salary increments (Law et al., 2004). As a result of the aforementioned studies, it has been established that emotional intelligence plays a major and crucial influence in employee career advancement and success.

\section{Literature Related to the Emotional Intelligence and Career}

Chagelishvili's (2021) inquiry on the role of emotional intelligence in career success and human resource development indicated that emotional intelligence aids employees in a variety of ways to achieve career success, also known as career growth. Similarly, Vibhor et al. (2020) researched the function of emotional intelligence in career performance. Their research discovered a link between emotional intelligence and professional success and growth. In addition, Suleman et al. (2020) looked into the connection between emotional intelligence and job satisfaction among school principals. Their research discovered a moderately positive association between emotional intelligence and school principals' work satisfaction.

Urquijo, Extremera, and Azanza's (2019) study of the role of emotional intelligence in job performance found that emotional intelligence is a useful tool for achieving career success. Khanzada et al., (2018) researched the association between emotional intelligence and teacher job performance and found that there was a noteworthy positive relationship between emotional intelligence and teacher work performance as well as career development. Similarly, Gabel et al., (2017) investigated the function of emotional intelligence in professional adjustment and success, finding that emotional intelligence played a favorable role in career adjustment and success. Sultana, Yousaf, Khan, and Saeed (2016) present research on the impact of emotional intelligence on perceived career success. According to their findings, there is a significant link between career dedication and career success. Furthermore, Nima et al., (2015) found a favorable and significant influence of emotional intelligence on job performance in their research. Nikic, Travica, and Mitrovic (2014) discovered a strong and favorable relationship between emotional competency and job advancement and success in their study. Yuan, Tan, Huang, and Zou (2013) established a link between emotional intelligence and job satisfaction. Tareef's (2012) investigation into the association between emotional intelligence and career growth and advancement of faculty members in higher education discovered a positive correlation between emotional intelligence and career advancements.

Given the above researches, it has been exposed that previous latest studies available in literature discovered positive and significant effects of emotional intelligence on career advancement, career growth, and career success. Moreover, several studies highlighted that employees with high levels of emotional intelligence had enhanced career advancement, job performance, and efficient management skills (Gabel et al., 2017). Therefore, literature has concluded that there was a positive role of emotional intelligence in the career advancement of university teachers.

\section{CONCLUSION}

In the light of the aforesaid critical analysis of the literature, it has been revealed that emotional intelligence contributes towards teachers' retention, progress, success, growth, and career advancement in every organization. The organization with fewer opportunities for upward career advancement fails to achieve the status of a good logo. Literature proved that emotional intelligence has three mental-process elements: appraising and articulating emotions in oneself and others, adapting emotions in oneself and others, and adaptive usage of emotions. These elements form teachers' ability to connect with others emotionally and one's deep understanding of self-awareness, self-regulation, social awareness, and relationship management and are also considered for career advancements, growth, as well as success.

\section{LIMITATION OF THE STUDY}

The scope of this research is limited to a review of the literature on the impact of emotional intelligence on professional advancement and success. The researcher relied solely on secondary data to investigate the association between the two variables. As a result, future researchers should devise a strategy for determining the association between the two variables by obtaining original data from university teachers.

\section{CONFLICT OF INTEREST AND ETHICAL STANDARDS}

It is clarified that no conflict of interest exists with any organization, and it is assured that no unethical practices have been followed during the study.

\section{AUTHOR'S CONTRIBUTION}

All of the authors worked together to complete this study. The authors of this research study have also contributed under their assigned responsibilities. All the authors fulfilled their specific responsibilities to make this article appropriate. 


\section{REFERENCES}

1. Adeniji, A., Falola, H., Salau, O.(2014). A modelling relationship between work satisfaction and faculty performance in the Nigerian private universities. European Scientific Journal, 10(32), 63-80.

2. Adeniji, A., Osibanjo, O., Salau, O., Falola, H., Igbinoba, E., Ohunakin, F. and Ogueyungbo, O. (2019). Competence model for measuring career development and organizational growth in the health sector. Business. Theory and Practice, 20, 248-258. https://doi.org/10.3846/btp.2019.24

3. Armstrong, M. (2011). A handbook of human resource management practice, 12th ed. London: Kogan Page

4. Bar-On, R. (1997). Bar-One Emotional Quotient Inventory: Technical manual. Toronto: Multi-Health Systems.

5. Bombuwela, P.M., De Alwis, A.C. (2013). Effects of glass ceiling on women career development in private sector organizations - Case of Sri Lanka. Journal of Competitiveness, 5(2), 3-19. https://doi.org/10.7 441/joc.2013.02.01

6. Boyatzis, R., \& Sala, F. (2004). The Emotional Competency Inventory (ECI). In G. Geher (Ed.), Measuring emotional intelligence: Common ground and controversy (pp. 143-178). Hauppauge, NY: Nova Science.

7. Carter, N., \& Silva, C. (2011). The myth of the ideal worker. Catalyst. Retrieved from: www.catalyst.org

8. Chagelishvili, A. (2021). The Contribution of Emotional Intelligence to Human Resource Development and Career Success: A Review, European Journal of Economics and Business Studies, 7(2), 49-59. https://doi.org/10.26417/628dhv60q

9. Cherniss, C. (2010). Emotional intelligence: Toward clarification of a concept. Industrial and Organizational Psychology, 3, 110-126. https://doi.org/10.1111/j.1754-9434.2010.01231.x

10. Colman, A. (2008). A Dictionary of Psychology (3 ed.). Oxford University Press

11. Deci, E. L., \& Ryan, R. M. (1985). The general causality orientations scale: Self-determination in personality. Journal of Research in Personality, 19, 109-134. https://doi.org/10.1016/0092-6566(85)90023-6

12. Dries, R. (2011). Career Advancement and Family Balance Strategies of Executive Women. Gender in Management: An International Journal, 24(6), 388-411. https://doi.org/10.1108/17542410910980388

13. Duque, J.L., Garcia, M., Hurtado, A. (2017). Influencia de la inteligencia emocional sobre las competencias laborales: Un estudio empírico con empleados del nivel administrativo. Estud. Gerenc., 33, 250-260. https://doi.org/10.1016/j.estger.2017.06.005

14. Feldman Barrett, L., Gross, J., Christensen, T. C., \& Benvenuto, M. (2001). Knowing what you're feeling and knowing what to do about it: Mapping the relation between emotion differentiation and emotion regulation. Cognition and Emotion, 15, 713-724. https://doi.org/10.1080/02699930143000239

15. Frolich, N.; Wendt, K.K.; Reymert, I.; Tellmann, S.M.; Elken, M.; Kyvik, S.; Vabo, A.; Larsen, E. (2018). Academic Career Structures in Europe: Perspectives from Norway, Denmark, Sweden, Finland, The Netherlands, Austria and the U.K.; NIFU: Oslo, Norway.

16. Gabel, R. S., Dolan, S. L., \& Cerdin, J. L. (2005). Emotional intelligence as a predictor of cultural adjustment for success in global assignments. Career Development International, 10, 375-395. https://doi.org/10.110 8/13620430510615300

17. Gardner, H.(2013).The theory of multiple intelligences. Teaching and Learning in the Secondary School, 38, 171-189.

18. Godleman, D. (1994). Emotional Intelligence. Bantam Books.

19. Goh, C. H., Nam, H. G., Park, Y. S. (2003). Stress memory in plants: A negative regulation of stomatal response and transient induction of $\mathrm{rd} 22$ gene to light in abscisic acid-entrained Arabidopsis plants. The Plant Journal, 36(2), 240-255. https://doi.org/10.1046/j.1365-313X.2003.01872.X

20. Goleman, D. (1995). Emotional intelligence: Why it can matter more than I.Q. New York: Bantam Books.

21. Goleman, D. (2001). Working with Emotional Intelligence. Ljubljana: Mladinska knjiga.

22. Goleman, D. (2013). Emotional intelligence: Why it can matter more than I.Q. Bantam Books.

23. Greenhaus, J. H. (1987). Career management. Chicago: Dryden Press.

24. Gross, J.J. (1998). The emerging field of emotion regulation: An integrative review. Review of General Psychology, 2, 271-299. https://doi.org/10.1037/1089-2680.2.3.271

25. Herzberg, F., Mausner, B., \& Snyderman, B. B. (1959). The Motivation to Work, 2nd Edn. New York, NY: John Wiley \& Sons.

26. Ignat, A.A., \& Clipa, O. (2012). Teachers' satisfaction with life, jobs at is faction and their emotional intelligence. Procedia-Social and Behavioral Sciences, 33, 498-502. https://doi.org/10.1016/j.sbspro .2012 .01 .171

27. Karsli, M.D. (2008). Basic Concepts of Education and New Approaches. Eitim Bilimine Giriú. Introduction to Education Sciences, (2. B.). Ankara: Pegem Akademi.

28. Khanzada, B., Naeem, S., and Butt, H. (2018). Emotional intelligence influences on employee's/organizational performance with mediating role of job satisfaction in pakistani health sector. J. Health Educ. Res. Dev, 6, 1-6. https://doi.org/10.4172/2380-5439.1000253

29. Khan, K. M., Ullah M. (2021). Mediating Role of Ethical Leadership Between Employees Empowerment and Competitive Edge: A Case of Commercial Banks in Pakistan. Humanities \& Social Sciences Reviews, 9(2), 219-231. https://doi.org/10.18510/hssr.2021.9223 
30. King, Z. (2004). Career self-management: Its nature, causes and consequences. Journal of Vocational Behavior, 65,112-133. https://doi.org/10.1016/S0001-8791(03)00052-6

31. Lahti, E. (2013). Women and Leadership: Factors that Influence Women's Career Success. Finland: Lahti University.

32. Law, K.S., Wong, C.S, \& Song, L.J. (2004). The construct and criterion validity of emotional intelligence and its potential utility for management studies. The Journal of Applied Psychology, 89(3), 483-96. https://doi.org/10.1037/0021-9010.89.3.483

33. Maimunah, I., Atikah, N.R., (2016). Influence of cultural values on career goal of an intergenerational workforce in a Malaysian industrial corporation. European Journal of Business and Social Sciences, 4(12), 4657.

34. Mardanpour, M., and Makvandi, B. (2015). The relationship between emotional intelligence and job satisfaction in the staff of insurance companies in Ahwaz. Iran. Int. J. Rev. Life Sci. 5, 982-989.

35. Mayer, J. D., Caruso, D. R., \& Salovey, P. (1999). Emotional intelligence meets traditional standards for intelligence. Intelligence, 27, 267-298. https://doi.org/10.1016/S0160-2896(99)00016-1

36. Mayer, J. D., Salovey, P., \& Caruso, D. R. (2013). Emotional intelligence: New ability or eclectic traits? American psychologist, 63(6), 500-503. https://doi.org/10.1037/0003-066X.63.6.503

37. Mayer, J. D., Salovey, P., Caruso, D. R., \& Sitarenios, G. (2003). Measuring emotional intelligence with the MSCEIT V2.0. Emotion, 3, 97-105. https://doi.org/10.1037/1528-3542.3.1.97

38. Mayer, J.D., \& Salovey, P. (1997). What is emotional intelligence? In P. Salovey \& D.J. Sluyter (Eds.), Emotional Development and Emotional Intelligence: Educational Implications: 3-31. New York: Basic Book.

39. Miner, J. B., Chen, C.C., \& Yu, K. C. (1991). Theory testing under adverse conditions. Journal of Applied Psychology, 76, 343-349. https://doi.org/10.1037/0021-9010.76.3.343

40. Murniati, C. (2012). Career advancement of women senior academic administrators in Indonesia: Supports and challenges. USA: University of Iowa.

41. Nikic, G., Travica,V., Mitrovic, M. (2014). Differences Between Employees and Managers Regarding SocioEmotional Competencies. Serbian Journal of Management, 9(2), 281-292. https://doi.org/10.5937/sjm9-5440

42. Nima, S., Mahmood, H., Saeid, A. M. \& Mousavian, S.(2015). Studying the Influence of Emotional Intelligence on Career Success, J. Basic. Appl. Sci. Res., 2(12), 12255-12260.

43. Ohunakin, F., Adeniji, A., Oludayo, O., Osibanjo, A.(2018). Survey dataset on leadership styles and job satisfaction: the perspective of employees of hospitality providers. Data in Brief, 19, 2178-2188. https://doi.org/10.1016/j.dib.2018.06.033

44. Petrides, K. V., \& Furnham, A. (2003). Trait emotional intelligence: Behavioural validation in two studies of emotion recognition and reactivity to mood induction. European Journal of Personality, 17, 39-57. https://doi.org/10.1002/per.466

45. Salau, O., Adeniji, A., Oyewunmi, E. (2014). Relationship between elements of job enrichment and organizational performance among the Non-academic staff in Nigerian Public Universities. Management \& Marketing, 12(2), 112-119.

46. Salovey, P., \& Mayer,J.D.(1990).Emotional intelligence. Imagination, Cognition and Personality, 9(3), 185211. https://doi.org/10.2190/DUGG-P24E-52WK-6CDG

47. Seibert, S. E., Kraimer, M. L., Holtom, B. C., \& Pierotti, A. J. (2013). Even the best laid plans sometimes go askew: Career self-management processes, career shocks, and the decision to pursue graduate education. Journal of Applied Psychology, 98, 169-182. https://doi.org/10.1037/a0030882

48. Serbanescu, L. (2011). Professional training for teachers. Bucureşti: Editura Printech, (Chapter 4). (in Romanian).

49. Steiner, C. (1984). Emotional literacy. Transactional Analysis Journal, 14(3), 162-173. https://doi.org/10.1 177/036215378401400301

50. Suleman, Q., Ali, M.S., Ziarab, M.\& Ishtiaq, H.(2020).Correlating Emotional Intelligence With Job Satisfaction: Evidence From a Cross-Sectional Study Among Secondary School Heads in Khyber Pakhtunkhwa, Pakistan. Frontiers in Psychology, 11, 240-251. https://doi.org/10.3389/fpsyg.2020.00240

51. Sultana, R., Yousaf, A., Khan, I. and Saeed, A. (2016). Probing the interactive effects of career commitment and emotional intelligence on perceived objective/subjective career success. Personnel Review, 45(4), 724-742. https://doi.org/10.1108/PR-11-2014-0265

52. Tareef, A. (2012). The relationship between mentoring and career development of higher education faculty members. College Student Journal, 18, 703-710.

53. Thorndike, R.K.(1920).Intelligence and its uses. Harper's Magazine, 140, 227-335.

54. Urquijo, I., Extremera, N., \& Azanza, G. (2019). The Contribution of Emotional Intelligence to Career Success: Beyond Personality Traits. International journal of environmental research and public health, 16(23), 48094819. https://doi.org/10.3390/ijerph16234809

55. Ullah, M., Hamdard, M.N., (2019). CEO Duality and Risk: A Case of Textile Firms Listed on Pakistan Stock Exchange. North American Academic Research, 2(11), 122-131.

56. Weinert, A. B. (2001). Psychology of career development. International Encyclopedia of the Social \& Behavioural Sciences, Elsevier Science, 1471-1476. https://doi.org/10.1016/B0-08-043076-7/01399-1 
57. Williams, G. C., Hedberg, V. A., Cox, E. M., \& Deci, E. L.(2000). Extrinsic life goals and healthrisk behaviors in adolescents. Journal of Applied Social Psychology, 30, 1756-1771. https://doi.org/10.1111/j.15591816.2000.tb02466.X

58. Yuan L., Tan X., Huang C., Zou F. (2013). mediating effect of job satisfaction on the relationship between emotional intelligence and perceived general health. Social Behavior and Personality: An international journal, 42(7),1057-1068. https://doi.org/10.2224/sbp.2014.42.7.1057 